\title{
BMJ Open Ethnic disparities in the prevalence of metabolic syndrome and its risk factors in the Suriname Health Study: a cross-sectional population study
}

\author{
Ingrid S K Krishnadath, ${ }^{1}$ Jerry R Toelsie, ${ }^{2}$ Albert Hofman, ${ }^{3}$ Vincent W V Jaddoe ${ }^{3,4}$
}

To cite: Krishnadath ISK, Toelsie JR, Hofman A, et al. Ethnic disparities in the prevalence of metabolic syndrome and its risk factors in the Suriname Health Study: a cross-sectional population study. BMJ Open 2016;6:e013183

doi:10.1136/bmjopen-2016013183

- Prepublication history for this paper is available online. To view these files please visit the journal online (http://dx.doi.org/10.1136/ bmjopen-2016-013183).

Received 27 June 2016 Revised 15 November 2016 Accepted 16 November 2016

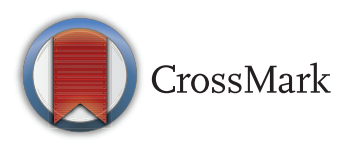

\footnotetext{
${ }^{1}$ Department of Public Health, Faculty of Medical Sciences, Anton de Kom University of Suriname, Paramaribo, Suriname

${ }^{2}$ Department of Physiology, Faculty of Medical Sciences, Anton de Kom University of Suriname, Paramaribo, Suriname

${ }^{3}$ Department of

Epidemiology, Erasmus MC University Medical Center,

Rotterdam, The Netherlands ${ }^{4}$ Department of Pediatrics,

Erasmus MC, University

Medical Center, Rotterdam,

The Netherlands
}

Correspondence to Dr Ingrid S K Krishnadath; Ingrid.Krishnadath@uvs.edu

\section{ABSTRACT}

Background: The metabolic syndrome (MetS) indicates increased risk for cardiovascular disease and type 2 diabetes. We estimated the overall and ethnicspecific prevalence of MetS and explored the associations of risk factors with MetS among Amerindian, Creole, Hindustani, Javanese, Maroon and Mixed ethnic groups.

Method: We used the 2009 Joint Interim Statement (JIS) to define MetS in a subgroup of 2946 participants of the Suriname Health Study, a national survey designed according to the WHO Steps guidelines. The prevalences of MetS and its components were determined for all ethnicities. Hierarchical logistic regressions were used to determine the associations of ethnicity, sex, age, marital status, educational level, income status, employment, smoking status, residence, physical activity, fruit and vegetable intake with MetS.

Results: The overall estimated prevalence of MetS was $39.2 \%$. From MetS components, central obesity and low high-density lipoprotein cholesterol (HDL-C) had the highest prevalences. The prevalence of MetS was highest for the Hindustanis (52.7\%) and lowest for Maroons (24.2\%). The analyses showed that in the overall population sex (women: OR $1.4 ; 95 \% \mathrm{Cl} 1.2$ to 1.6), age (OR $5.5 \mathrm{Cl} 4.3$ to 7.2 ), education (OR $0.7 \mathrm{Cl}$ 0.6 to 0.9 ), living area ( $\mathrm{OR} 0.6 \mathrm{Cl} 0.5$ to 0.8 ), income (OR $0.7 \mathrm{Cl} 0.5$ to 0.9 ) and marital status (OR $1.3 \mathrm{Cl}$ 1.1 to 1.6$)$ were associated with MetS. Variations observed in the associations of the risk factors with MetS in the ethnic groups did not materially influence the associations of ethnicities with MetS.

Conclusions: The prevalence of MetS was high and varied widely among ethnicities. Overall, central obesity and low HDL-C contributed most to MetS. Further studies are needed to assess the prospective associations of risk factors with MetS in different ethnic groups.

\section{INTRODUCTION}

The metabolic syndrome (MetS) refers to the clustering of risk factors for cardiovascular disease (CVD) and diabetes, which occur
Strengths and limitations of this study

- The design of the study included a stratified multistage cluster sample, which represents the ethnic and geographic diversity within the Surinamese population by sex in five different age groups.

- Use of sample weights in the analysis to correct for selection and response bias.

- A low percentage of missing data in general.

- The wide range of variables evaluated in this study allowed control for confounders in the evaluation of associations, but still residual confounding cannot be excluded.

- This is a cross-sectional study with associated limitations and further studies are needed to assess the prospective associations of risk factors with metabolic syndrome in different ethnic groups.

together more often than by chance alone. ${ }^{1}$ Currently used MetS definitions include central obesity, increased blood pressure, elevated blood glucose and triglyceride, and decreased high-density lipoprotein cholesterol (HDL-C) concentrations. The International Diabetes Federation (IDF) definition and the 2009 Joint Interim Statement $(\mathrm{JIS})^{1}$ have shown a high level of agreement in the risk for CVD. ${ }^{2}{ }^{3}$ It has been estimated that around $20-25 \%$ of the world's adult population has MetS. In comparison to people without MetS, people with MetS have twice the risk of dying from GVD and five times the risk of developing type 2 diabetes. ${ }^{4}$ Previous studies have shown that both genetic and lifestyle factors, such as smoking, impaired physical activity and high-energy dense food intake, affect the different components of MetS. ${ }^{5}$ There is growing evidence that demographic factors like urbanisation and low socioeconomic status are associated with increased risk of MetS. ${ }^{6-10}$ Ethnic disparities in the prevalence of MetS have been 
described. Higher prevalences have been reported among the Hispanics, Amerindians and people of Indian descent and lower prevalences among the Inuits, blacks and Chinese. ${ }^{1}{ }^{511-14}$ It has been demonstrated that the racial and ethnic composition of a population influences the sex-related differences in MetS prevalence. ${ }^{15}$ The Republic of Suriname, located in the northeast of South America, is an upper-middle income Caribbean country, ${ }^{16}$ which has a multiethnic population consisting mainly of people of Indian, African, Indonesian and Amerindian descent. ${ }^{16}$ In each of these ethnic groups, cardiovascular disease and diabetes are the main causes of morbidity and mortality. ${ }^{17}$ Data from the Suriname Health Study on pre-diabetes and diabetes showed a prevalence of $13 \%$ for diabetes overall and of $23.3 \%$ in the Hindustanis. ${ }^{19}{ }^{20}$ The MetS components described in this analysis indicated the highest median values for central obesity in the Amerindians and Hindustanis, the highest mean systolic blood pressure values in the Creoles and the mean values for blood glucose and blood lipids most approaching deviating values in the Javanese and Hindustanis. ${ }^{19}$ Although these components were described, MetS was not evaluated. The only publication on MetS in the Caribbean concerns data of a 1993-2001 cohort study that reports a prevalence of $21.1 \%$ in Jamaica. $^{8}$

We used data from the Suriname Health Study, the first nationwide study on non-communicable disease (NCD) risk factors ${ }^{20}$ to estimate the prevalence of MetS as well as to assess the main risk factors in different ethnic subgroups. We also explored the influence of biological, demographic and/or lifestyle risk factors on ethnic differences in the association with MetS.

\section{METHODS}

We used a subgroup of 2646 participants (20-65 years) of the Suriname Health Study. ${ }^{20}$ The Suriname Health Study, a cross-sectional population study, was designed according to the WHO Steps guidelines ${ }^{21}$ and approved by the Ethics Committee of the Ministry of Health. Suriname has $\sim 550000$ inhabitants, categorised into 15.7\% Creoles (descendants of African plantation slaves), 27.4\% Hindustanis (descendants of Indians), 13.7\% Javanese (descendants of Indonesians), 21.7\% Maroons (descendants of African refugees who escaped slavery), $13.4 \%$ Mixed ethnicity, $7.6 \%$ others including Amerindians (original inhabitants) and $0.6 \%$ unknown. ${ }^{16}$ Participants were categorised into a specific ethnic group if at least three of the four grandparents were of the same ethnicity. Anybody else was of mixed ethnicity. As described previously, ${ }^{20}$ this study used a stratified multistage cluster sample of households to select respondents between March and September 2013. In total, 343 clusters were selected randomly within the enumeration areas of the 10 districts of Suriname. Except for the 16 clusters with 40 households in the remote district, Sipaliwini, each cluster contained 25 households. With a Kish grid, ${ }^{22}$ which is a preassigned table of random numbers, the respondents were identified in the selected household, informed about the details of the study and then asked to sign for consent. The medical section of the research team revised the physical and biochemical measurements and provided advices or referred to the general practitioner in cases with an adverse outcome. The respondents received the written results of their physical and biochemical measures. The subgroup for this study comprised 2646 participants with 9 hours overnight-fasting blood samples available.

\section{Outcome measures}

We used interviews with questionnaires, physical and biochemical measurements to collect information. The questionnaire included questions on the use of antihypertensive and antidiabetic medication, but no specific questions on triglyceride lowering or HDL-C increasing medication.

We measured WC with the Seca 201 measuring tape in centimetres $(\mathrm{cm})$ at a level midway between the lowest rib and the iliac crest. ${ }^{20}$

Blood samples were collected after 9 hours of overnight fasting in order to determine the levels of blood glucose, cholesterol and triglycerides by a WASO 9001 2008 certified laboratory. Participating staff was trained extensively according to the WHO Steps manual. ${ }^{21}$ MetS was defined as any three of the following five components; ${ }^{1}$

1. Increased WC. This was defined according to the recommended cut-off values in the JIS definition. On the basis of their ethnic background, we categorised Hindustani, Javanese, Amerindian and Mixed ethnicities as South Asians and South and Central Americans, and used the corresponding cut-off points $(>90 \mathrm{~cm}$ in men and $>80 \mathrm{~cm}$ in women) for increased waist. The cut-off values for the sub-Saharan Africans $(>94 \mathrm{~cm}$ in men and $>80 \mathrm{~cm}$ in women) were used in Creoles and Maroons;

2. Raised fasting blood glucose levels $(>5.5 \mathrm{mmol} / \mathrm{L}$ or use of diabetes medication);

3. Raised blood pressure (systolic blood pressure $\geq 130 \mathrm{~mm} \mathrm{Hg}$, diastolic blood pressure $\geq 85 \mathrm{~mm} \mathrm{Hg}$ or use of antihypertensive medication);

4. Raised triglycerides $(\geq 1.7 \mathrm{mmol} / \mathrm{L})$;

5. Low HDL-C $(<1.0 \mathrm{mmol} / \mathrm{L}$ in men and $<1.3 \mathrm{mmol} / \mathrm{L}$ in women).

As previously described ${ }^{20}$ we considered several risk factors. 'Biological factors' included sex and age. 'Demographic factors' included residential area, marital status, educational level, income status and employment. The residential addresses were stratified into urban, rural coastal areas and the rural interior. ${ }^{23}$ Educational levels were divided into low (primary school education or lower), middle (middle or secondary education) and high (above middle or secondary) education. 
Household income was classified as the income status quintile from the Ministry of Internal Affairs of Suriname in Surinamese dollars, SRD (\$US1=SRD3.35). The first quintile corresponded to the lowest income and the fifth to the highest. Owing to the small number of respondents in the fourth and fifth quintiles, these two were combined in the analysis. Working and studying participants were classified as employed. 'Lifestyle factors' included cigarette smoking (daily smokers), fruit and vegetable consumption (average daily portions) and physical activity (in metabolic equivalent of task (MET) minutes). Fruit and vegetable consumption and physical activity were classified according to the WHO recommendations. Smoking was categorised as non-daily and daily smokers. Fruit and vegetable consumption was divided in groups of $\geq 5$ or $<5$ average fruit/vegetable portions daily. ${ }^{24-27}$ Physical activity was measured by the global physical activity questionnaire (GPAQ) and categorised into $<600 \mathrm{MET}$ or $>=600 \mathrm{MET}^{24}$

\section{Statistical analysis}

First, we assessed participants' characteristics and described the distribution of risk factors overall and among ethnic groups. Second, we calculated the estimated prevalence of MetS and its components, overall, by sex and ethnicity. The differences in percentages, means and medians between various ethnic groups were assessed with the Pearson's $\chi^{2}$, analysis of variance ANOVA or Kruskal-Wallis test, respectively. To adjust for $\alpha$ inflation $(\alpha=0.05)$ the Bonferroni procedure was used as a post hoc test (significance level $\mathrm{p}<0.05$ ).

Third, we used multiple logistic regression to examine the associations of various risk factors with MetS, adjusted for sex and age, in the overall population and within each ethnic group. Fourth, the risk for MetS between the largest ethnic group, the Hindustanis (reference group) and other ethnic groups was evaluated with hierarchical multiple logistic regression. We used four separate logistic regression models to analyse both the separate effects of biological factors, demographic factors and lifestyle factors, and their combined effects on the observed associations. The first model comprised the base multivariate model adjusted for the biological factors (sex, age). In addition to this base model (model 1 ), we adjusted for demographic factors in model 2 (residential area, marital status, educational level, income status and employment). In model 3, we added lifestyle factors (cigarette smoking, fruit and vegetable consumption and physical activity) to model 1 , and in model 4 we evaluated all risk factors. The results in the various models were compared. We used weighted data for all analyses and considered the statistical significance at $p$ values $<0.05$. The weights used for analysis were calculated to correct for probability of selection, non-response and differences between the sample population and target population. We used the statistical software Epi Info V.3.2 and the Statistical Packages for Social Sciences (SPSS V.21.0) for analyses.

\section{RESULTS}

Table 1 shows that the highest percentage of men was found in the Creoles and the highest mean age in the Javanese. We found low education and income most frequently in the Amerindians. The highest percentage of smokers was observed among the Creoles, whereas the lowest percentage of participants who met the required level of physical activity was observed among the Maroons. Amerindians had the lowest percentage of participants who consumed the minimal required fruit and vegetables, and had the highest WC. The mean values for BMI and SBP did not differ significantly between the ethnicities. The highest values for diastolic blood pressure, median fasting blood glucose and median triglycerides were observed in the Hindustanis. The lowest values for HCL-C were observed in the Amerindians as well as Hindustanis. The highest values for MetS parameters were found in the Hindustanis.

Table 2 shows that the overall estimated prevalence of MetS was $39.2 \%$ (95\% CI $37.4 \%$ to $41.1 \%)$. The prevalence of MetS was higher among women (42.3\%) than men $(36.8 \%)$. Table 2 also shows higher prevalences of central obesity (57.4\%) and HDL-C (52.8\%) among the components of MetS in the overall population. Among the ethnic groups, the highest prevalence of MetS was observed among the Hindustanis $(52.7 \%)$, followed by the Amerindians (48.1\%) and Javanese (45\%). The difference between these groups was not statistically significant. The two lowest prevalences were observed among the Creoles $(29.0 \%)$ and Maroons (24.2\%). The differences in MetS between men and women were only significant among the Creoles and Maroons where we observed more MetS in women $(35.8 \%$ and $33.04 \%$, respectively) compared to men $(24.1 \%$ and $10.1 \%$, respectively). The prevalence of central obesity was highest from the MetS components in all ethnic groups and reached up to $80.8 \%$ in the Amerindian women. Among the Amerindians, Hindustanis and Javanese, the prevalences of increased glucose and lipid concentrations were higher compared to the prevalences of increased systolic and diastolic blood pressure. Among the Creoles, Maroons and Mixed ethnicities the prevalences of increased systolic and diastolic blood pressure were higher compared to increased glucose and lipid concentrations.

Figure 1 shows the prevalence of MetS by age and ethnicity. The overall prevalence of MetS was $11.1 \%$ in the youngest age group (20-24 years), which increased with age and reached $60.7 \%$ in the oldest age group (6064 years). Among the Amerindians, Creoles, Hindustanis and Maroons, the prevalence of MetS peaked in the age group of 55-59 years and declined in the older group.

Table 3 describes the OR for MetS by various risk factors in the overall population and in the various ethnic groups. In the overall population, the association for MetS in women was stronger than in men. The association of older people, lower educated people, people living in urban areas and married people for MetS was 
Table 1 Participant characteristics, overall and per ethnic group $(\mathrm{N}=2646)$, including the prevalence of MetS

\begin{tabular}{|c|c|c|c|c|c|c|c|}
\hline & $\begin{array}{l}\text { Overall population } \\
\mathrm{N}=2646\end{array}$ & $\begin{array}{l}\text { Amerindian } \\
\mathrm{N}=211\end{array}$ & $\begin{array}{l}\text { Creole } \\
\mathrm{N}=321\end{array}$ & $\begin{array}{l}\text { Hindustani } \\
\mathrm{N}=740\end{array}$ & $\begin{array}{l}\text { Javanese } \\
\mathrm{N}=434\end{array}$ & $\begin{array}{l}\text { Maroon } \\
\mathrm{N}=576\end{array}$ & $\begin{array}{l}\text { Mixed ethnicity } \\
\mathrm{N}=327\end{array}$ \\
\hline Men \% (95\% Cl) & 48.5 (46.6 to 50.5$)$ & $36.2(27.3 \text { to } 45.7)^{b, c, d}$ & $58.3(52.7 \text { to } 63.7)^{a, e, f}$ & $53.5(50.2 \text { to } 56.7)^{a, d}$ & $51.9(47.1 \text { to } 56.8)^{\mathrm{a}, \mathrm{d}}$ & $38.8(34.2 \text { to } 43.6)^{b, c, d}$ & $45.7(40.6 \text { to } 50.8)^{b}$ \\
\hline Age, mean (SD) years & $39.2(12.2)$ & $40.0(12.0)^{\mathrm{e}}$ & $39.5(13.2)^{\mathrm{e}}$ & $40.4(11.7)^{\mathrm{e}}$ & $41.6(11.5)^{\mathrm{e}, \mathrm{f}}$ & $35.6(11.6)^{a, b, c, d, f f}$ & $38.8(12.6)^{\mathrm{d}, \mathrm{e}}$ \\
\hline \multicolumn{8}{|l|}{ Education \% $(95 \% \mathrm{Cl})$} \\
\hline Low & $52.5(50.5$ to 54.4$)$ & $80.2(71.6 \text { to } 87.2)^{\text {b,c,d.f }}$ & $37.6(32.1 \text { to } 43.2)^{\mathrm{a}, \mathrm{c}, \mathrm{d}, \mathrm{e}}$ & $54.6(51.2 \text { to } 57.9)^{\mathrm{a}, \mathrm{b}, \mathrm{e}, \mathrm{f}}$ & $51.9(47.0 \text { to } 56.8)^{\mathrm{a}, \mathrm{b}, \mathrm{e}, \mathrm{f}}$ & $67.4(62.6 \text { to } 71.9)^{\mathrm{b}, \mathrm{c}, \mathrm{d}, \mathrm{f}}$ & $32.2(27.4 \text { to } 37.4)^{\mathrm{a}, \mathrm{c}, \mathrm{d}, \mathrm{e}}$ \\
\hline Middle & 27.1 (25.3 to 28.9 ) & $16.5(9.9 \text { to } 24.5)^{\mathrm{b}, \mathrm{d}, \mathrm{f}}$ & $32.3(27.1 \text { to } 37.9)^{\mathrm{a}, \mathrm{e}}$ & 27.1 (24.2 to 30.2 ) & $33.5(29.1 \text { to } 38.3)^{\mathrm{a}, \mathrm{e}}$ & $19.7(16.1 \text { to } 23.9)^{\mathrm{b}, \mathrm{d}, \mathrm{f}}$ & $31.7(26.9 \text { to } 36.9)^{\mathrm{a}, \mathrm{e}}$ \\
\hline High & 20.5 (18.9 to 22.1$)$ & $3.2(1.0 \text { to } 8.9)^{\mathrm{b}, \mathrm{c}, \mathrm{d}, \mathrm{f}}$ & $30.2(25.1 \text { to } 35.7)^{\mathrm{a}, \mathrm{c}, \mathrm{d}, \mathrm{f}}$ & $18.3(15.9 \text { to } 21.1)^{a, b, f}$ & $14.6(11.4 \text { to } 18.4)^{\mathrm{a}, \mathrm{b}, \mathrm{f}}$ & $12.9(9.9 \text { to } 16.6)^{\mathrm{b}, \mathrm{f}}$ & $36.1(31.1 \text { to } 41.4)^{\mathrm{a}, \mathrm{c}, \mathrm{d}, \mathrm{e}}$ \\
\hline \multicolumn{8}{|l|}{ Income status $\%(95 \% \mathrm{Cl})$} \\
\hline q1-lowest & 33.5 (31.1 to 35.9 ) & $59.1(46.0 \text { to } 71.3)^{\mathrm{b}, \mathrm{c}, \mathrm{d}, \mathrm{f}}$ & $21.3(15.8 \text { to } 28.2)^{\mathrm{a}, \mathrm{e}}$ & $30.9(27.0 \text { to } 35.1)^{\mathrm{a}, \mathrm{e}}$ & $21.4(16.8 \text { to } 26.9)^{\mathrm{a}, \mathrm{e}}$ & $53.7(47.4 \text { to } 59.9)^{\mathrm{b}, \mathrm{c}, \mathrm{d}, \mathrm{f}}$ & $20.6(15.3 \text { to } 26.7)^{\mathrm{a}, \mathrm{e}}$ \\
\hline q2 & 34.0 (31.6 to 36.4$)$ & 25.7 (15.2 to 37.9$)$ & $41.6(34.3$ to 49.1$) \mathrm{f}$ & $37.3(33.2 \text { to } 41.6)^{f}$ & 39.1 (33.3 to 45.2$) f$ & 32.6 (26.9 to 38.7$)$ & $24.3(18.7 \text { to } 30.8)^{b, c, d}$ \\
\hline q3 & $15.0(13.3$ to 16.9$)$ & $4.1(1.0$ to 13.1$)$ & $20.7(14.9$ to 27.1$) \mathrm{e}$ & $17.8(14.6 \text { to } 21.4)^{\mathrm{e}}$ & $18.8(14.5$ to 24.1$) \mathrm{e}$ & $7.1(4.1 \text { to } 10.7)^{\mathrm{b}, \mathrm{c}, \mathrm{d}, \mathrm{f}}$ & $17.6(12.8 \text { to } 23.6)^{\mathrm{e}}$ \\
\hline $\mathrm{q} 4$ and q5-highest & 17.5 (15.7 to 19.6$)$ & $11.0(4.5 \text { to } 21.4)^{f}$ & $16.3(11.5$ to 22.8$) e, f$ & $14.0(11.2 \text { to } 17.3)^{\mathrm{e}, \mathrm{f}}$ & 20.6 (15.9 to 25.8$) e, f$ & $6.7(3.8 \text { to } 10.2)^{\text {bcdf }}$ & $37.4(30.8 \text { to } 44.3)^{a, b, c, d, e}$ \\
\hline \multicolumn{8}{|l|}{ Residential area \% $(95 \% \mathrm{Cl})$} \\
\hline Urban coastal & 74.7 (73.1 to 76.5$)$ & $29.7(21.6 \text { to } 39.1)^{\mathrm{b}, \mathrm{c}, \mathrm{d}, \mathrm{e}, \mathrm{f}}$ & $86.2(81.9 \text { to } 89.7)^{\mathrm{a}, \mathrm{d}, \mathrm{e}}$ & $84.8(82.3 \text { to } 87.0)^{a, d, e}$ & 75.4 (71.0 to 79.4$)^{a, b, c, e, f}$ & $57.3(52.4 \text { to } 62.0)^{a, b, b, c, d, f}$ & $88.2(84.4 \text { to } 91.2)^{\mathrm{a}, \mathrm{d}, \mathrm{e}}$ \\
\hline Rural coastal & $14.9(13.5$ to 16.3$)$ & 29.0 (20.9 to 38.3$)^{b, c, e, f}$ & $13.8(10.3 \text { to } 18.1)^{\mathrm{a}, \mathrm{d}, \mathrm{e}}$ & $15.2(13.0 \text { to } 17.7)^{\mathrm{a}, \mathrm{d}, \mathrm{e}}$ & $24.6(20.6 \text { to } 29.0)^{\mathrm{b}, \mathrm{c}, \mathrm{e}, \mathrm{f}}$ & $6.9(4.8 \text { to } 9.9)^{\mathrm{a}, \mathrm{b}, \mathrm{c}, \mathrm{d}, \mathrm{d}}$ & $11.8(8.8 \text { to } 15.6)^{\mathrm{a}, \mathrm{d}}$ \\
\hline Rural interior & $10.3(9.2$ to 11.5$)$ & $41.3(32.2 \text { to } 51.0)^{b, c, d, f}$ & $0(0 \text { to } 1.5)^{a, e}$ & $0(0 \text { to } 0.5)^{a, e}$ & $0(0 \text { to } 1.1)^{a, e}$ & 35.8 (31.3 to 40.6 ) b,c,d,f & $0(0 \text { to } 1.3)^{a, e}$ \\
\hline Living with partner $\%(95 \% \mathrm{Cl})$ & $58.4(56.5$ to 60.3$)$ & $75.1(66.3 \text { to } 82.9)^{\mathrm{b}, \mathrm{e}, \mathrm{f}}$ & $30.7(25.8 \text { to } 36.1)^{\mathrm{a}, \mathrm{c}, \mathrm{d}, \mathrm{e}, \mathrm{f}}$ & $70.4(67.3 \text { to } 73.3)^{\mathrm{b}, \mathrm{d}, \mathrm{e}, \mathrm{f}}$ & $80.1(75.9 \text { to } 83.8)^{\mathrm{b}, \mathrm{c}, \mathrm{e}, \mathrm{f}}$ & $46.5(41.6 \text { to } 51.4)^{\mathrm{a}, \mathrm{b}, \mathrm{c}, \mathrm{d}}$ & $52.0(46.8 \text { to } 57.2)^{a, b, c, c, d}$ \\
\hline Employed \% $(95 \% \mathrm{Cl})$ & $71.2(69.5$ to 73.0$)$ & $38.0(29.8 \text { to } 48.5)^{b, c, d, e, f}$ & $84.6(80.2 \text { to } 88.4)^{\mathrm{a}, \mathrm{c}, \mathrm{e}}$ & $70.0(66.9 \text { to } 72.9)^{\mathrm{a}, \mathrm{b}, \mathrm{f}}$ & $76.3(71.9 \text { to } 80.2)^{\mathrm{a}, \mathrm{e}}$ & $63.4(58.6 \text { to } 67.9)^{\mathrm{a}, \mathrm{b}, \mathrm{d}, \mathrm{f}}$ & $80.8(76.5 \text { to } 84.7)^{\mathrm{a}, \mathrm{c}, \mathrm{e}}$ \\
\hline Smoking \% $(95 \% \mathrm{Cl})$ & 21.4 (19.9 to 23.1$)$ & $12.1(6.9 \text { to } 19.8)^{\mathrm{b}, \mathrm{d}, \mathrm{f}}$ & 31.5 (26.5 to 36.9$)^{\mathrm{a}, \mathrm{c}, \mathrm{e}}$ & $20.2(17.7 \text { to } 23.0)^{\mathrm{b}, \mathrm{d}, \mathrm{e}}$ & $29.7(25.4 \text { to } 34.3)^{a, c, e, e}$ & $9.9(7.3 \text { to } 13.2)^{\mathrm{b}, \mathrm{c}, \mathrm{d}, \mathrm{f}, \mathrm{f}}$ & $25.9(21.5 \text { to } 30.7)^{\mathrm{a}, \mathrm{e}}$ \\
\hline Rec. physical activity \% (95\% Cl) & $64.3(62.2$ to 66.2$)$ & 61.5 (50.2 to 72.2$)$ & 71.6 (65.8 to 76.8 ) & $64.6(61.1$ to 67.9$)$ & 62.8 (57.7 to 67.6 ) & 60.9 (55.6 to 66.1$)$ & 63.3 (57.8 to 68.5 ) \\
\hline $\begin{array}{l}\text { Rec. fruit and veg. cons. \% } \\
(95 \% \mathrm{Cl})\end{array}$ & $15.9(14.5$ to 17.4$)$ & $7.3(3.3 \text { to } 14.1)^{d}$ & $18.0(14.0$ to 22.7$)$ & $15.6(13.3$ to 18.2$)$ & $18.3(14.8$ to 22.5$)$ & $12.6(9.5$ to 16.5$) \mathrm{a}$ & $20.5(16.6$ to 25.1$)$ \\
\hline Body mass index, mean (SD) & $27.3(5.9)$ & $28.6(5.6)$ & $27.1(6.1)$ & $27.0(5.6)$ & $27.4(5.5)$ & $27.3(6.2)$ & $27.4(6.1)$ \\
\hline Waist circumference, mean (SD) & $89.6(15.0)$ & $92.8(14.5)^{\mathrm{d}, \mathrm{e}}$ & $88.7(15.3)^{\mathrm{c}}$ & $91.7(15.3)^{\mathrm{b}, \mathrm{d}, \mathrm{e}}$ & $87.6(13.0)^{\mathrm{a}, \mathrm{c}}$ & $87.5(14.7)^{\mathrm{a}, \mathrm{c}}$ & $90.0(16.2)$ \\
\hline SBP, mean (SD) $\mathrm{mm} \mathrm{Hg}$ & $121.1(19.4)$ & $119.8(17.9)$ & $123.9(20.1)$ & $120.9(19.4)$ & $121.5(19.7)$ & $120.2(18.7)$ & $120.2(20.6)$ \\
\hline $\mathrm{DBP}$, mean (SD) $\mathrm{mm} \mathrm{Hg}$ & $80.1(12.5)$ & $78.1(11.2)$ & $80.3(13.3)$ & $80.9(12.1)$ & $81.0(12.7)$ & $79.2(13.0)$ & $79.5(12.3)$ \\
\hline $\mathrm{FBG}$, median (IQ) $\mathrm{mmol} / \mathrm{L}$ & $5.4(5.0$ to 5.9$)$ & $5.4(5.1 \text { to } 6.0)^{\mathrm{b}, \mathrm{c}, \mathrm{e}}$ & $5.2(4.9 \text { to } 5.8)^{\mathrm{a}, \mathrm{c}, \mathrm{e}, \mathrm{f}}$ & $5.6(5.2 \text { to } 6.5)^{a, b, d, e, f f}$ & $5.3(4.9$ to 6.0$) \mathrm{e}$ & $5.1(4.8 \text { to } 5.6)^{\mathrm{a}, \mathrm{b}, \mathrm{c}, \mathrm{d}, \mathrm{f}}$ & $5.4(5.0 \text { to } 5.8)^{\mathrm{b}, \mathrm{c}, \mathrm{d}}$ \\
\hline $\mathrm{HDL}-\mathrm{C}$, median $(\mathrm{IQ}) \mathrm{mmol} / \mathrm{L}$ & $1.1(1.0$ to 1.3$)$ & $1.1(0.9 \text { to } 1.3)^{\mathrm{b}, \mathrm{e}}$ & $1.2(1.0 \text { to } 1.4)^{\mathrm{a}, \mathrm{ac}, \mathrm{d}, \mathrm{f}}$ & $1.1(0.9 \text { to } 1.2)^{\mathrm{b}, \mathrm{e}, \mathrm{f}}$ & $1.1(1.0 \text { to } 1.3)^{\mathrm{b}, \mathrm{e}, \mathrm{f}}$ & $1.2(1.1 \text { to } 1.4)^{\mathrm{a}, \mathrm{a}, \mathrm{d}, \mathrm{f}}$ & $1.1(1.0 \text { to } 1.3)^{\mathrm{b}, \mathrm{c}, \mathrm{d}, \mathrm{e}}$ \\
\hline Triglycerides median (IQ) $\mathrm{mmol} / \mathrm{L}$ & $1.0(0.7$ to 1.6$)$ & $1.2(0.9 \text { to } 2.1)^{\mathrm{b}, \mathrm{e}, \mathrm{f}}$ & $0.8(0.6 \text { to } 1.2)^{a, c, d, e, f}$ & $1.2(0.8 \text { to } 1.8)^{\mathrm{b}, \mathrm{e}, \mathrm{f}}$ & $1.3(0.9 \text { to } 2.2)^{b, e, f}$ & $0.8(0.5 \text { to } 1.1)^{a, b, c, d, f}$ & $1.0(0.7 \text { to } 1.5)^{\mathrm{a}, \mathrm{b}, \mathrm{c}, \mathrm{d}, \mathrm{e}}$ \\
\hline
\end{tabular}


Table 2 The prevalence of components of the metabolic syndrome

\begin{tabular}{|c|c|c|c|c|c|c|c|}
\hline & $\begin{array}{l}\text { Overall pop. } \\
\mathrm{N}=2646\end{array}$ & $\begin{array}{l}\text { Amerindian } \\
\mathrm{N}=211\end{array}$ & $\begin{array}{l}\text { Creole } \\
\mathrm{N}=321\end{array}$ & $\begin{array}{l}\text { Hindustani } \\
\mathrm{N}=740\end{array}$ & $\begin{array}{l}\text { Javanese } \\
\mathrm{N}=434\end{array}$ & $\begin{array}{l}\text { Maroon } \\
\mathrm{N}=576\end{array}$ & $\begin{array}{l}\text { Mixed ethnicity } \\
\mathrm{N}=327\end{array}$ \\
\hline Increased waist circumference $\%(\mathrm{Cl})^{*}$ & 57.4 (55.5 to 59.3$)$ & $71.6(62.5$ to 79.8$)$ & 46.5 (40.9 to 52.0$)$ & 65.5 (62.3 to 68.6$)$ & $52.3(47.4$ to 57.1$)$ & $52.2(47.4$ to 57.1$)$ & $60.1(54.9$ to 65.0$)$ \\
\hline Systolic blood pressure $\geq 130 \mathrm{~mm} \mathrm{Hg} \%(\mathrm{Cl})$ & 25.6 (23.9 to 27.3$)$ & 26.6 (18.9 to 35.7$)$ & 29.5 (24.7 to 34.9$)$ & 27.5 (24.7 to 30.5$)$ & 25.8 (21.8 to 30.3$)$ & 23.9 (20.0 to 28.3$)$ & $21.5(17.5$ to 26.0$)$ \\
\hline Diastolic blood pressure $\geq 85 \mathrm{~mm} \mathrm{Hg} \%(\mathrm{Cl})$ & $31.3(29.6$ to 33.1$)$ & 26.8 (18.7 to 35.6$)$ & 32.3 (27.3 to 37.7$)$ & 36.2 (33.1 to 39.4$)$ & 34.6 (30.2 to 39.4$)$ & 25.5 (21.5 to 30.0$)$ & 28.7 (24.2 to 33.6$)$ \\
\hline Fasting blood glucose $>5.5 \mathrm{mmol} / \mathrm{L} \%$ or medic $(\mathrm{Cl}) \dagger$ & 40.2 (38.2 to 41.9$)$ & $40.2(31.3$ to 50.0$)$ & 31.5 (26.5 to 36.9$)$ & 56.5 (53.2 to 59.7$)$ & 40.1 (35.4 to 44.9$)$ & 26.3 (22.2 to 30.8$)$ & 38.3 (33.4 to 43.4$)$ \\
\hline Low high-density lipoprotein \% (Cl)‡ & 52.8 (50.9 to 54.7 ) & 63.5 (54.2 to 72.6$)$ & 39.8 (34.4 to 45.3 ) & $64.2(61.0$ to 67.3$)$ & 58.6 (53.7 to 63.3 ) & 42.5 (37.78 to 47.4$)$ & 50.1 (44.9 to 55.2$)$ \\
\hline Triglycerides $\geq 1.7 \mathrm{mmol} / \mathrm{L} \%(\mathrm{Cl})$ & 22.0 (20.5 to 23.7$)$ & $33.4(24.8$ to 42.9$)$ & $10.7(7.7$ to 14.7$)$ & 30.6 (27.7 to 33.7$)$ & 35.0 (30.5 to 39.7$)$ & $7.7(5.4$ to 10.8$)$ & $19.3(15.5$ to 23.7$)$ \\
\hline MetS \% $(\mathrm{Cl})$ & $39.2(37.4$ to 41.1$)$ & 48.1 (38.8 to 57.7$)$ & $29(24.2$ to 34.3$)$ & $52.7(49.4$ to 56$)$ & $45(40.2$ to 49.8$)$ & 24.2 (20.3 to 28.6$)$ & 35.4 (30.6 to 40.5$)$ \\
\hline Women & $\mathrm{N}=1752$ & $\mathrm{~N}=\mathbf{1 6 1}$ & $\mathrm{N}=\mathbf{1 7 3}$ & $\mathrm{N}=467$ & $\mathrm{~N}=263$ & $\mathrm{~N}=443$ & $\mathrm{~N}=103$ \\
\hline Waist circumference $>80 \mathrm{~cm} \%(\mathrm{Cl})$ & 72.9 (70.4.1 to 75.2$)$ & $80.8(69.8$ to 89.0$)$ & 77.1 (69.2 to 83.9$)$ & 73.3 (68.9 to 77.4$)$ & 65.9 (59.0 to 72.4$)$ & 73.6 (67.8. to 78.8$)$ & $69.4(62.5$ to 75.6$)$ \\
\hline Systolic blood pressure $\geq 130 \mathrm{~mm} \mathrm{Hg} \%(\mathrm{Cl})$ & $20.8(18.7$ to 23.1$)$ & 18.2 (9.8 to 28.8$)$ & 24.1 (17.3 to 32.4$)$ & 19.9 (16.3 to 24.1$)$ & $24.8(19.1$ to 31.4$)$ & 23.5 (18.4 to 29.1$)$ & $15.2(10.5$ to 20.8$)$ \\
\hline Diastolic blood pressure $\geq 85 \mathrm{~mm} \mathrm{Hg} \%$ (Cl) & 28.7 (26.3 to 31.2$)$ & $18.7(10.9$ to 30.1$)$ & 36.0 (28.1 to 44.9$)$ & 29.3 (25.1 to 33.9$)$ & 33.8 (27.3 to 40.7$)$ & 28.5 (23.0 to 34.4$)$ & 24.6 (18.7 to 30.9$)$ \\
\hline Fasting blood glucose $>5.5 \mathrm{mmol} / \mathrm{L} \%(\mathrm{Cl})$ & 39.9 (37.3 to 42.6$)$ & $38.5(27.6$ to 50.6$)$ & $28.3(20.7$ to 36.5$)$ & $56.2(51.3$ to 60.9$)$ & $44.4(37.4$ to 51.4$)$ & $28.2(22.7$ to 34.0$)$ & 37.5 (30.9 to 44.6$)$ \\
\hline High density lipoprotein $<1.3 \mathrm{mmol} / \mathrm{L} \%$ (Cl) & 59.0 (56.3 to 61.6$)$ & $71.2(59.2$ to 81.1$)$ & 49.1 (40.6 to 57.9 ) & $73.6(69.1$ to 77.7$)$ & $58.0(51.0$ to 64.9$)$ & $52.9(46.5$ to 59.0$)$ & $50.0(43.1$ to 57.2$)$ \\
\hline Triglycerides $\geq 1.7 \mathrm{mmol} / \mathrm{L} \%(\mathrm{Cl})$ & $15.7(13.8$ to 17.8$)$ & 31.0 (20.2 to 42.5$)$ & $4.4(1.6$ to 9.4$)$ & 21.5 (17.8 to 25.8$)$ & $29.3(23.1$ to 36.0$)$ & 6.5 (3.8 to 10.2$)$ & $10.7(6.9$ to 15.8$)$ \\
\hline MetS \% (Cl) & 42.3 (39.7 to 45.0$)$ & 49.4 (37.7 to 61.2$)$ & 35.8 (27.9 to 44.6$)$ & 49.4 (42.5 to 56.4$)$ & $53.2(48.4$ to 58.0$)$ & $33(27.4$ to 39.0$)$ & $34.6(28.1$ to 41.5$)$ \\
\hline Men & $\mathrm{N}=894$ & $\mathrm{~N}=50$ & $\mathrm{~N}=148$ & $\mathrm{~N}=273$ & $\mathrm{~N}=265$ & $\mathrm{~N}=133$ & $\mathrm{~N}=224$ \\
\hline Waist circumference $>90 \mathrm{~cm}$ or $94 \mathrm{~cm} \%(\mathrm{Cl}) \S$ & 41.1 (38.4 to 43.8$)$ & 55.3 (39.4 to 71.3$)$ & 24.7 (18.8 to 31.5$)$ & 58.7 (54.2 to 63.0$)$ & 39.7 (33.2 to 46.4$)$ & $18.5(13.0$ to 25.4$)$ & $49.0(41.2$ to 56.6$)$ \\
\hline Systolic blood pressure $\geq 130 \mathrm{~mm} \mathrm{Hg} \%$ (Cl) & 30.7 (28.2 to 33.3$)$ & 41.9 (26.4 to 58.0$)$ & 33.4 (26.6 to 40.5$)$ & 34.2 (30.1 to 38.6$)$ & 26.7 (20.9 to 33.0$)$ & 24.5 (18.3 to 31.9$)$ & 28.9 (22.4 to 36.4$)$ \\
\hline Diastolic blood pressure $\geq 85 \mathrm{~mm} \mathrm{Hg} \%$ (Cl) & 34.1 (31.5 to 36.8$)$ & $41.0(26.1$ to 57.6$)$ & 29.6 (23.2 to 36.9$)$ & 42.2 (37.8 to 46.7$)$ & 35.4 (28.9 to 41.9$)$ & 20.8 (15.1 to 28.0$)$ & 33.6 (26.7 to 41.2$)$ \\
\hline Fasting blood glucose $>5.5 \mathrm{mmol} / \mathrm{L} \%(\mathrm{Cl})$ & 40.6 (37.9 to 43.3$)$ & 41.1 (26.2 to 57.6$)$ & 33.7 (27 to 40.9$)$ & 56.8 (52.3 to 61.2$)$ & 36.1 (29.7 to 42.8$)$ & $23.3(17.2$ to 30.6$)$ & $39.2(32.1$ to 47.1$)$ \\
\hline High density lipoprotein $<1.0 \mathrm{mmol} / \mathrm{L} \%(\mathrm{Cl})$ & $46.2(43.4$ to 49.0$)$ & 50.0 (34.6 to 66.3$)$ & 33.0 (26.5 to 40.3$)$ & 55.9 (51.4 to 60.4$)$ & 59.1 (52.3 to 65.6$)$ & 26.4 (19.9 to 33.9$)$ & 50.1 (42.4 to 57.8$)$ \\
\hline Triglycerides $\geq 1.7 \mathrm{mmol} / \mathrm{L} \%(\mathrm{Cl})$ & 28.8 (26.3 to 31.4$)$ & 37.5 (22.3 to 53.4$)$ & $15.2(10.5$ to 21.2$)$ & 38.5 (34.3 to 43.0$)$ & 40.3 (33.7 to 46.9$)$ & 9.6 (5.6 to 15.2$)$ & 29.5 (22.9 to 37.0$)$ \\
\hline MetS\% $(\mathrm{Cl})$ & 36.8 (33.4 to 38.7 ) & 45.7 (30.4 to 62.2 ) & 24.1 (18.3 to 31$)$ & 40.9 (34.4 to 47.7$)$ & 52.3 (47.8 to 56.8$)$ & $10.1(6.1$ to 15.9$)$ & 36.4 (29.3 to 44.2$)$ \\
\hline
\end{tabular}


Figure 1 Prevalence of MetS by age and ethnicity. Figure 1 showing the prevalence of the metabolic syndrome in 5 years age strata for the total population and for the Amerindian, Creole, Hindustani, Javanese, Maroon and Mixed ethnic groups. MetS, metabolic syndrome.

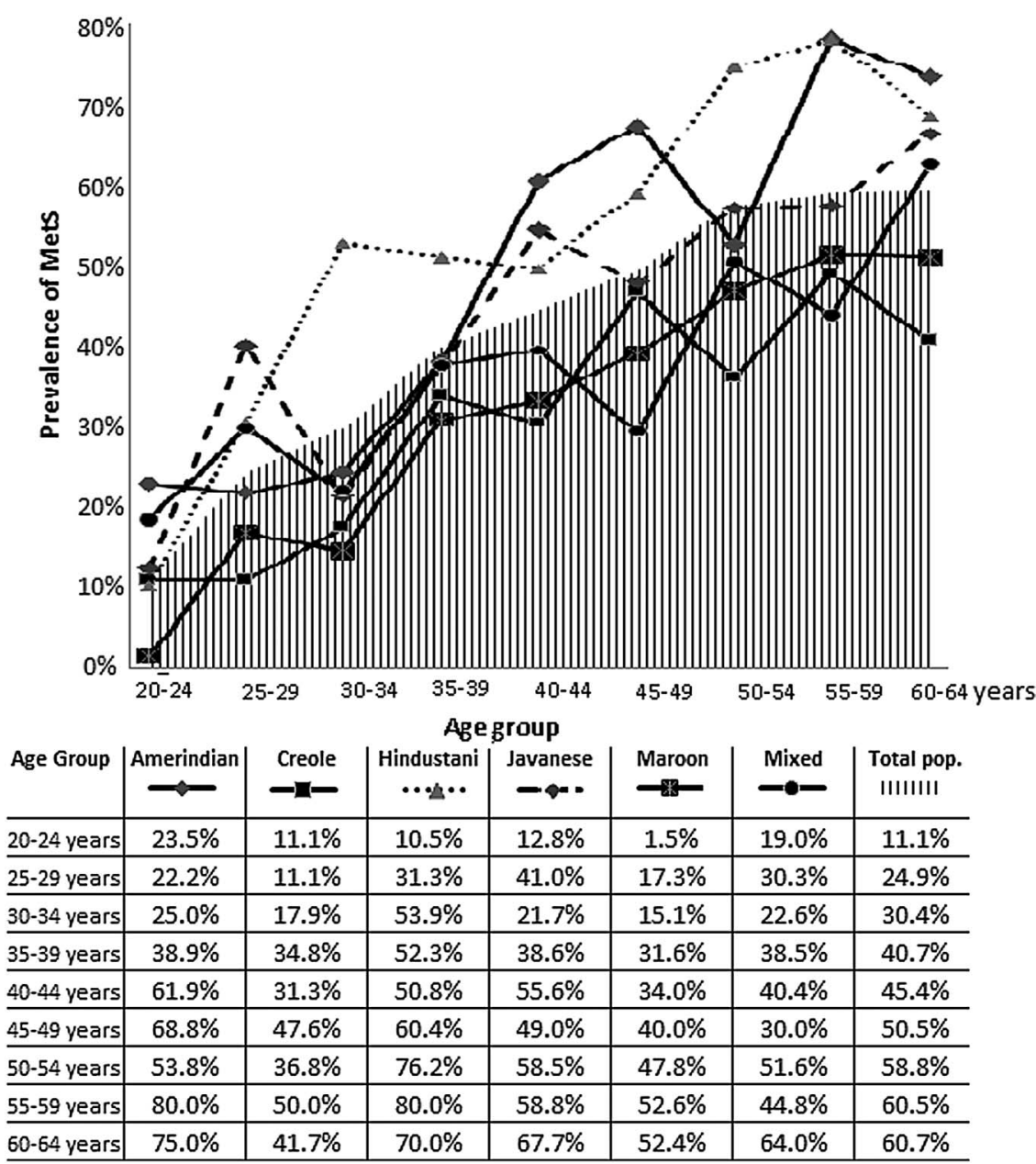

more pronounced in comparison with younger people, highly educated people, people living in the rural interior and single people, respectively. In all ethnic groups, the OR for MetS was higher in the older age groups. The steepest incline of the OR for age groups was observed among the Amerindians and Maroons, whereas the most gradual incline was among the Mixed participants. In addition to the increasing OR with age, in the Creoles unemployed people had a higher risk of MetS than employed people; in the Hindustanis, lower educated people and people with lower income had a stronger association compared to people with higher education and income, respectively; in the Javanese, women, people with lower income and people who consumed five or more portions of vegetables in a day had a stronger association compared to men, people with middle income and those who consumed less than five portions a day, respectively; in the Maroons, women had a stronger association compared to men; in Mixed ethnicity, married people showed for a more pronounced association for MetS compared to singles.

Table 4 shows that as compared to the Hindustanis, the Javanese, Creoles, Maroons and Mixed ethnicity had a lower risk of MetS. In the first model, the ORs in the ethnic groups varied from 0.3 (95\% CI 0.2 to 0.4$)$ in the Maroons, to 0.8 (95\% CI 0.6 to 1.2) in the Amerindians as compared to the Hindustanis. After additional adjustments for demographic and lifestyle factors, the effect

\section{DISCUSSION}

The overall prevalence of MetS was almost $40 \%$ higher in women and increased with age. This prevalence was highest among the Hindustanis, followed by the Amerindians and Javanese. Among the components of MetS, central obesity and low HDL-C were most prevalent. We observed associations for sex, age, education, income, residential area and marital status with MetS in the overall population. Within the ethnic groups, there was heterogeneity in the associations with the risk factors and MetS. However, the differences in the associations of ethnic groups with MetS were not explained by the variations in these risk factors.

Comparison in prevalence of MetS between studies and countries is difficult because various definitions are being used. The estimates based on the JIS and IDF definitions are comparable and exceed those estimates did not materially change. 
Table 3 ORs for MetS by various risk factors

\begin{tabular}{|c|c|c|c|c|c|c|c|}
\hline Characteristics & $\begin{array}{l}\text { Overall } \\
\mathrm{N}=2646\end{array}$ & $\begin{array}{l}\text { Amerindian } \\
\mathrm{N}=211\end{array}$ & $\begin{array}{l}\text { Creole } \\
\mathrm{N}=321\end{array}$ & $\begin{array}{l}\text { Hindustani } \\
\mathrm{N}=740\end{array}$ & $\begin{array}{l}\text { Javanese } \\
\mathrm{N}=434\end{array}$ & $\begin{array}{l}\text { Maroon } \\
\mathrm{N}=576\end{array}$ & $\begin{array}{l}\text { Mixed ethnicity } \\
\mathrm{N}=327\end{array}$ \\
\hline \multicolumn{8}{|l|}{$\overline{\text { Sex }}$} \\
\hline Male & 1 & 1 & 1 & 1 & 1 & 1 & 1 \\
\hline Female & $1.4(1.2 \text { to } 1.6)^{\star}$ & $1.8(0.8$ to 4.2$)$ & $1.9(1.2$ to 3.1$)$ * & $1.0(0.8$ to 1.4$)$ & $1.5(1.0 \text { to } 2.2)^{*}$ & $5.4(2.9 \text { to } 10.1)^{\star}$ & 0.9 (0.6 to 1.3$)$ \\
\hline \multicolumn{8}{|l|}{ Age (years) } \\
\hline $20-34$ & 1 & 1 & 1 & 1 & 1 & 1 & 1 \\
\hline $35-44$ & $2.7(2.2 \text { to } 3.4)^{\star}$ & $3.9(1.4 \text { to } 11.0)^{*}$ & $3.1(1.5$ to 6.7$)$ * & $2.0(1.4$ to 2.8$)$ * & $3.0(1.8$ to 5.2$)$ * & $3.6(2.0$ to 6.8$)$ * & $2.0(1.2$ to 3.5$)$ * \\
\hline $45-54$ & $4.2(3.4 \text { to } 5.3)^{\star}$ & $7.1(2.2 \text { to } 21.8)^{\star}$ & $4.9(2.5$ to 9.5$)$ * & $3.8(2.7$ to 5.4$)$ * & $3.8(2.2$ to 6.7$)$ * & $6.2(3.1$ to 12.4$)$ * & $2.1(1.1$ to 3.8$)$ * \\
\hline $55-64$ & $5.5(4.3 \text { to } 7.2)^{\star}$ & $11.0(2.5$ to 53.3$)$ * & $6.2(2.9$ to 13.0$)$ * & $5.6(3.5$ to 8.9$)$ * & $5.6(2.9$ to 10.7$)$ * & $8.3(3.8$ to 18.0$)$ * & $3.6(1.9$ to 7.0$)$ * \\
\hline \multicolumn{8}{|l|}{ Education } \\
\hline Low & 1 & 1 & 1 & 1 & 1 & 1 & 1 \\
\hline Middle & $0.9(0.7$ to 1.1$)$ & $1.0(0.3$ to 2.8$)$ & $1.1(0.6$ to 2.0$)$ & $1.1(0.8$ to 1.5$)$ & $0.6(0.4$ to 1.0$)$ & $0.3(0.1 \text { to } 0.8)^{\star}$ & $1.2(0.7$ to 2.1$)$ \\
\hline High & $0.7(0.6 \text { to } 0.9)^{\star}$ & $0.2(0.0$ to 2.9$)$ & $0.9(0.5$ to 1.7$)$ & $0.6(0.4 \text { to } 1.0)^{\star}$ & $0.7(0.4$ to 1.3$)$ & $0.7(0.3$ to 1.7$)$ & $1.2(0.7$ to 2.1$)$ \\
\hline \multicolumn{8}{|l|}{ Income status } \\
\hline q1-lowest & 1 & 1 & 1 & 1 & 1 & 1 & 1 \\
\hline q2 & 0.8 (0.7 to 1.1$)$ & 2.2 (0.6 to 8.2$)$ & 0.7 (0.3 to 1.7$)$ & 0.8 (0.5 to 1.2$)$ & $0.3(0.2 \text { to } 0.6)^{\star}$ & 1.3 (0.5 to 2.4$)$ & 0.9 (0.4 to 2.2$)$ \\
\hline q3 & $1.1(0.8$ to 1.5$)$ & $1.1(0.1$ to 17.5$)$ & $2.2(0.8$ to 6.1$)$ & $1.5(0.9$ to 2.7$)$ & $0.3(0.1 \text { to } 0.7)^{*}$ & 0.5 (0.1 to 2.0$)$ & $0.7(0.3$ to 1.8$)$ \\
\hline q4 and q5-highest & $0.7(0.5 \text { to } 0.9)^{*}$ & $0.9(0.2$ to 5.0$)$ & 1.4 (0.5 to 4.0$)$ & $0.5(0.3 \text { to } 0.9)^{*}$ & 0.6 (0.3 to 1.3$)$ & 0.4 (0.1 to 2.7$)$ & 0.5 (0.2 to 1.2$)$ \\
\hline \multicolumn{8}{|l|}{ Residential area } \\
\hline Urban coastal & 1 & 1 & 1 & 1 & 1 & 1 & 1 \\
\hline Rural coastal & $1.2(1.0$ to 1.5$)$ & 0.9 (0.3 to 2.6$)$ & $1.0(0.5$ to 2.1$)$ & $1.4(0.9$ to 2.1$)$ & $1.0(0.6$ to 1.6$)$ & $1.4(0.6$ to 3.7$)$ & 1.1 (0.6 to 2.2$)$ \\
\hline Rural interior & $0.6(0.5 \text { to } 0.8)^{*}$ & $0.6(0.2$ to 1.6$)$ & NA & NA & NA & $0.9(0.5$ to 1.6$)$ & NA \\
\hline \multicolumn{8}{|l|}{ Marital status } \\
\hline Not married & 1 & 1 & 1 & 1 & 1 & 1 & 1 \\
\hline Married & $1.3(1.1 \text { to } 1.6)^{*}$ & $0.5(0.2$ to 1.4$)$ & $1.1(0.6$ to 1.9$)$ & $1.1(0.8$ to 1.5$)$ & $0.9(0.6$ to 1.6$)$ & $0.9(0.6$ to 1.5$))$ & $1.6(1.0 \text { to } 2.5)^{*}$ \\
\hline \multicolumn{8}{|l|}{ Employment } \\
\hline Employed & 1 & 1 & 1 & 1 & 1 & 1 & 1 \\
\hline Not employed & $0.9(0.8$ to 1.1$)$ & $0.5(0.2$ to 1.1$)$ & $0.4(0.2 \text { to } 1.0)^{*}$ & 0.9 (0.6 to 1.3$)$ & $1.0(0.6$ to 1.7$)$ & $1.0(0.6$ to 1.7$)$ & $1.0(0.6$ to 1.9$)$ \\
\hline \multicolumn{8}{|l|}{ Smoking status } \\
\hline Not smoking & 1 & 1 & 1 & 1 & 1 & 1 & 1 \\
\hline Smoking & $0.8(0.7$ to 1.0$)$ & 0.9 (0.2 to 3.2$)$ & $1.4(0.8$ to 2.7$)$ & 0.7 (0.5 to 1.0$)$ & $0.9(0.5$ to 1.4$)$ & 0.8 (0.3 to 2.4$)$ & $0.9(0.5$ to 1.5$)$ \\
\hline \multicolumn{8}{|l|}{ Physical activity } \\
\hline $\mathrm{MET}<600$ & 1 & 1 & 1 & 1 & 1 & 1 & 1 \\
\hline $\mathrm{MET} \geq 600$ & $0.9(0.7$ to 1.1$)$ & $0.8(0.3$ to 2.3$)$ & $1.1(0.6$ to 2.0$)$ & $0.7(0.5$ to 1.0$)$ & $0.9(0.6$ to 1.4$)$ & $1.1(0.7$ to 2.0$)$ & $1.0(0.6$ to 1.5$)$ \\
\hline \multicolumn{8}{|c|}{ Fruit and vegetable consumption } \\
\hline$<5$ portions/day & 1 & 1 & 1 & 1 & 1 & 1 & 1 \\
\hline$\geq 5$ portions/day & $1.0(0.8$ to 1.2$)$ & $1.2(0.2$ to 5.8$)$ & $0.8(0.4$ to 1.6$)$ & $0.8(0.5$ to 1.2$)$ & $1.7(1.0 \text { to } 3.0)^{*}$ & $1.3(0.5$ to 3.0$)$ & $1.0(0.6$ to 1.7$)$ \\
\hline
\end{tabular}

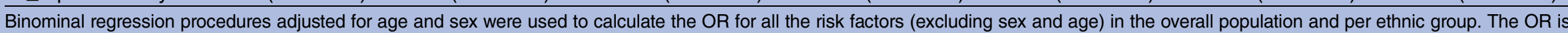
considered significant with a $p$ value below $0.05\left({ }^{*}=p<0.05\right)$. NA indicates not applicable. The overall population also includes other ethnicities.

MET, metabolic equivalent of task; MetS, metabolic syndrome. 
Table 4 Models of association of MetS among ethnic groups

\begin{tabular}{|c|c|c|c|c|}
\hline Ethnic group & $\begin{array}{l}\text { Model } 1 \\
\text { OR }(95 \% \mathrm{Cl})\end{array}$ & $\begin{array}{l}\text { Model } 2 \\
\text { OR }(95 \% \mathrm{Cl})\end{array}$ & $\begin{array}{l}\text { Model } 3 \\
\text { OR }(95 \% \mathrm{Cl})\end{array}$ & $\begin{array}{l}\text { Model } 4 \\
\text { OR }(95 \% \mathrm{Cl}) \\
\end{array}$ \\
\hline Hindustani & 1 & 1 & 1 & 1 \\
\hline Amerindian & 0.8 (0.6 to 1.2$)$ & $0.6(0.4$ to 1.0$)$ & 1.0 (0.6 to 1.5$)$ & $0.7(0.4$ to 1.4$)$ \\
\hline Creole & $0.3(0.3 \text { to } 0.5)^{\star}$ & $0.4(0.3 \text { to } 0.6)^{*}$ & $0.4(0.3 \text { to } 0.5)^{\star}$ & $0.5(0.3 \text { to } 0.7)^{\star}$ \\
\hline Javanese & $0.7(0.5 \text { to } 0.9)^{*}$ & $0.6(0.4 \text { to } 0.8)^{*}$ & $0.7(0.5 \text { to } 0.9)^{*}$ & $0.6(0.4 \text { to } 0.8)^{\star}$ \\
\hline Maroon & $0.3(0.2 \text { to } 0.4)^{*}$ & $0.3(0.2 \text { to } 0.4)^{*}$ & $0.3(0.2 \text { to } 0.4)^{\star}$ & $0.3(0.2 \text { to } 0.5)^{*}$ \\
\hline Mixed & $0.5(0.4 \text { to } 0.6)^{*}$ & $0.4(0.3 \text { to } 0.6)^{*}$ & $0.5(0.4 \text { to } 0.7)^{\star}$ & $0.5(0.3 \text { to } 0.8)^{\star}$ \\
\hline
\end{tabular}

Model 1 is the basic multivariate model adjusted for sex and age.

Model 2 is adjusted for variables in model 1 plus demographic factors like living area, marital status, education, income and working status.

Model 3 is adjusted for variables in model 1 plus lifestyle factors like smoking, physical activity and consumption of fruits and vegetables.

Model 4 is adjusted for variables in models $1,2,3$.

${ }^{*} \mathrm{p} \leq 0.05$ The OR is significant.

MetS, metabolic syndrome.

determined with other definitions. ${ }^{2}{ }^{28}$ The prevalence for Europe, ${ }^{329}{ }^{30}$ North, and South East Asia ${ }^{31}$ of JIS defined Mets varied between $27 \%$ and $33 \%$. The JIS defined prevalence of the MetS in Suriname was higher than that in European countries, but comparable to prevalences in South Asia. ${ }^{28}$ The prevalence we estimated in our study also exceeds the published prevalence in Jamaica. ${ }^{8}$ Since MetS portrays increased risk of CVD, the high MetS prevalence found in our study is reflected in the high mortality from CVD in Suriname. ${ }^{18}$

The distribution of the components of MetS can differ even when MetS prevalences are alike. High levels of central obesity are most common. In European studies, increased WC and hypertension are the main components, whereas ${ }^{29} 30$ in Asian studies, increased WC and increased fasting blood glucose prevail. ${ }^{28}$ In the present study, increased WC and low HDL-C values were most common. Results of a population-based study suggest that common genetic variants affect HDL-C levels. Non-synonymous mutations affecting the sequence variants were more common in individuals with low HDL-C compared to those with high HDL-C. ${ }^{32}$ So, apart from lifestyle factors, ethnic specific genetic components may also affect low HDL-C plasma levels. In order to develop effective prevention strategies, the MetS components should be explored in more depth.

As in other studies, we have observed that the prevalence of MetS increased with age and levelled or even decreased in the older categories. ${ }^{1} 33$ This difference may be due to selective survival with increased mortality rates. ${ }^{18}$ Available studies regarding the association between sex and MetS show inconsistent results, possibly influenced by the racial and ethnic composition of the study population, ${ }^{15} 34$ the level of sex hormones or age. ${ }^{34}$ Since no country-specific WC cut-off values are determined in Suriname, the JIS recommended cut-off values were used in our study. The recommended JIS values for participants of African descent are not in sync with studies, which suggest that WC cut-off values are lower for black men compared to women. ${ }^{35}{ }^{36}$ With the use of JIS values, we observed the largest discrepancy of central obesity and an association of sex with MetS in the Creoles and Maroons. Adapted JIS, WC cut-off values for blacks, with higher cut-off values for women compared to men, would have resulted in a different, maybe even inverse, association of sex with MetS in our study. However, changing the WC cut-off criteria will shift prevalence rates in women and men up or down, but whether it will be more effective to capture those who are at greatest risk of CVD and diabetes ${ }^{15}$ needs to be explored. More research, especially in groups with people of African descent, is needed in order to change the recommended cut-off values.

The higher prevalences, found among the Amerindians, Hindustanis and Javanese, are in line with published findings on MetS components from the Suriname Health Study. ${ }^{19}$ These findings also concur with the higher prevalences reported in the Mexicans and Hispanics in the USA. ${ }^{33} 37$ The extreme high prevalences we observed in Hindustani are comparable with published figures in populations like Malaysia, ${ }^{2}$ Sri Lanka $^{28}$ and India. ${ }^{39}$ The Masala Study shows that in South Asians only modestly increased BMI is already associated with high levels of total and regional adiposity. ${ }^{40}$ Also, increased levels of leptin were positively correlated with the MetS. ${ }^{40}$ Also, decreased insulin sensitivity and even more impaired $\beta$-cell function are associated with pre-diabetes and type 2 diabetes in Asian Indians. ${ }^{41}$ These findings suggest that descendants from South Asia have an increased risk of MetS. The lower prevalences of MetS that we found in the Creoles and Maroons are consistent with the lower prevalence among blacks in the USA. $^{33} 3738$ For ethnic groups with similar risk profiles like in our study, the role of genetic factors in the pathogenesis of MetS causes different interactions between genetic and environmental factors. ${ }^{15} 3842$ Studies on MetS components are reporting that in groups where hypertension prevails, lower prevalences of MetS are observed in contrast to groups where lipids or increased fasting blood glucose prevailed. ${ }^{2} 28$

The results of our study were consistent with the literature and underline the fact that ethnicity should be 
considered in the determination of MetS. More detailed ethnic-specific cohort and intervention studies are required to obtain this goal.

Previous studies are indicating that urbanisation, diet, smoking, education and levels of physical activity are important factors explaining the increasing risk of MetS. ${ }^{679}$ The results of this study are in line with those findings as most associations were observed for factors like residential area, education and income. However, in contrast to the previous studies, we observed that among the Javanese, higher intakes of fruits and vegetables are associated with a higher risk of MetS. ${ }^{15} 25$ To rule out confounding, the link between high intake of fruits and vegetables and risk behaviour like, for example, high intake of high-energy dense foods needs to be studied.

Differences in the prevalence of MetS components and their individual interaction with risk factors could explain the consistency in differences of association among ethnicities with $\mathrm{MetS}^{4}$ when adjusted for different risk models. Genetic factors may also explain part of the ethnic differences in MetS risk. ${ }^{15}$ In order to determine the impact of risk factors, more detailed research is needed.

The strength of this cross-sectional study was the design with a stratified multistage cluster, adequate to represent the ethnic and geographic diversity within the Surinamese population by sex in five different age groups. ${ }^{20}$ The use of trained interviewers, the inclusion of control questions in the questionnaire and the intense monitoring on consistency and completeness that included random checks on responses of participants improved the validity of our selfreported data. ${ }^{20}$ In addition, in the analysis, sample weights were applied in the analysis to correct for selection and response bias. In general, the percentage of missing data in general was relatively small $(<2 \%)$, except for the information on income status $(41.6 \%)$.

Still, some limitations should be considered. First, from all participants, 53\% met the criteria of 9 hours overnight fasting. Although sample weights were applied, the non-response for blood samples might have still resulted in self-selection bias, inflating the outcomes on prevalence. Second, although the wide range of variables evaluated in this study allowed control for confounders, residual confounding might still have occurred. For example, information on high-energy dense food intake was not considered.

\section{CONCLUSION}

The prevalence of the MetS in Suriname was higher than that in European countries, but comparable to prevalences in South Asia. The prevalence was the highest among the Hindustanis, followed by the Amerindians and Javanese. Central obesity and low HDL-C, especially in women, had the highest prevalence among the components of MetS. The prevalence of the different components of MetS varied between ethnicities. The observed heterogeneity in the associations with the risk factors and MetS among ethnicities did not influence the differences in OR for MetS among ethnic groups. The observed differences suggest that ethnicity should be considered in screening and for the development of preventive strategies for MetS. For more insight on the association of risk factors with MetS, further follow-up studies are needed.

Acknowledgements The authors thank Christel Smits, from the department of Public Health, Faculty of Medical Sciences, Anton de Kom University of Suriname, for her participation in data collection and control.

Contributors ISKK is the coordinator of this study and the guarantor of this work. ISKK conducted statistical analysis, reviewed the data and results, created tables and figures and wrote the manuscript. VWVJ assisted with project conception, collaborated in interpretation of data, reviewed and edited the manuscript. AH collaborated in interpretation of data, reviewed, edited and supervised the realisation of the manuscript. JRT assisted with project conception, collaborated in data collection, interpretation of data and reviewed and edited the manuscript. All Authors have full access to the data.

Funding The Suriname Heath Study was supported by the Ministry of Health in Suriname (contract number MOH/NCD/1220/GOS).

Competing interests None declared.

Ethics approval The protocol of the study was approved by the Ethics Committee of the Ministry of Health (Commissie mensgebonden wetenschappelijk onderzoek, reference (VG 004-2013)).

Provenance and peer review Not commissioned; externally peer reviewed.

Data sharing statement No additional data are available.

Open Access This is an Open Access article distributed in accordance with the Creative Commons Attribution Non Commercial (CC BY-NC 4.0) license, which permits others to distribute, remix, adapt, build upon this work noncommercially, and license their derivative works on different terms, provided the original work is properly cited and the use is non-commercial. See: http:// creativecommons.org/licenses/by-nc/4.0/

\section{REFERENCES}

1. Eckel RH AKGM, Grundy SM, Zimmet PZ. The metabolic syndrome. Lancet 2010;375:181-3.

2. Ramli AS, Daher AM, Nor-Ashikin MN, et al. JIS definition identified more Malaysian adults with metabolic syndrome compared to the NCEP-ATP III and IDF criteria. Biomed Res Int 2013;2013:760963.

3. Alkerwi A, Donneau AF, Sauvageot N, et al. Prevalence of the metabolic syndrome in Luxembourg according to the Joint Interim Statement definition estimated from the ORISCAV-LUX study. BMC public Health 2011;11:4.

4. Alberti G, Zimmet P, Shaw J, et al. The IDF consensus worldwide definition of the METABOLIC SYNDROME. Internat ional Diabetes Federat ion (IDF). 2006. http://www. idf.org・communi c ations @idf. org

5. Kraja AT, Rao DC, Weder AB, et al. An evaluation of the metabolic syndrome in a large multi-ethnic study: the Family Blood Pressure Program. Nutr Metab (Lond) 2005;2:17.

6. Assah FK, Ekelund U, Brage S, et al. Urbanization, physical activity, and metabolic health in sub-Saharan Africa. Diabetes Care 2011;34:491-6.

7. Adediran $\mathrm{O}$, Akintunde $\mathrm{AA}$, Edo $\mathrm{AE}$, et al. Impact of urbanization and gender on frequency of metabolic syndrome among native Abuja settlers in Nigeria. J Cardiovasc Dis Res 2012;3:191-6.

8. Ferguson TS, Younger N, Tulloch-Reid MK, et al. Prevalence of the metabolic syndrome in Jamaican adults and its relationship to income and education levels. West Indian Med J 2010;59:265-73.

9. Zhan Y, Yu J, Chen R, et al. Socioeconomic status and metabolic syndrome in the general population of China: a cross-sectional study. BMC Public Health 2012;12:921.

10. Montez JK, Bromberger JT, Harlow SD, et al. Life-course Socioeconomic Status and Metabolic Syndrome Among Midlife Women. J Gerontol B Psychol Sci Soc Sci 2016;71:1097-07.

11. Agyemang $\mathrm{C}$, van Valkengoed I, Hosper $\mathrm{K}$, et al. Educational inequalities in metabolic syndrome vary by ethnic group: evidence from the SUNSET study. Int J Cardiol 2010;141:266-74. 
12. Mohamud WN, Ismail AA, Sharifuddin A, et al. Prevalence of metabolic syndrome and its risk factors in adult Malaysians: results of a nationwide survey. Diabetes Res Clin Pract 2011;91:239-45.

13. Liu J, Hanley AJ, Young TK, et al. Characteristics and prevalence of the metabolic syndrome among three ethnic groups in Canada. Int J Obes (Lond) 2006;30:669-76.

14. Gurka MJ, Lilly CL, Oliver MN, et al. An examination of sex and racial/ethnic differences in the metabolic syndrome among adults: a confirmatory factor analysis and a resulting continuous severity score. Metab Clin Exp 2014;63:218-25.

15. Cornier MA, Dabelea D, Hernandez TL, et al. The metabolic syndrome. Endocr Rev 2008;29:777-822.

16. Algemeen Bureau voor de Statistiek, Censuskantoor, Suriname. Achtste (8e) Volks- en Woningtelling in Suriname (Volume I), Demografische en Socale karakteristieken en Migratie, 2013. http://unstats.un.org/unsd/demographic/sources/census/wphc/ Suriname/SUR-Census2012-vol1.pdf

17. Ministry of Health Suriname. Suriname National action plan for the prevention and control of noncommunicable diseases 2012-2016. http://www.iccp-portal.org/sites/default/files/plans/national_action_ plan_for_the_prevention_and_control_of_noncommunicable diseases_2012-2016.pdf

18. Punwasi W. Doodsoorzaken in Suriname 2009-2011. Paramaribo: Ministerie van Volksgezondheid, Bureau Openbare Gezondheidszorg, 2012.

19. Krishnadath IS, Nahar-van Venrooij LM, Jaddoe VW, et al. Ethnic differences in pre-diabetes and diabetes in the Suriname Health Study. BMJ Open Diabetes Res Care 2016;4:e000186.

20. Krishnadath IS, Smits CC, Jaddoe VW, et al. A National surveillance survey on noncommunicable disease risk factors: Suriname Health Study Protocol. JMIR Res Protoc 2015;4:e75.

21. WHO. Steps manual. Geneva: WHO Press, 2008. [updated 14 November 2008. http://www.who.int/chp/steps/manual/en/

22. Kish L. A procedure for objective respondent selection within the household. J Am Stat Assoc 1949;44:380-7.

23. Ministry of Social Affairs and Housing, General Bureau of Statistics. Suriname Multiple Indicator Cluster Survey 2010, Final Report. Paramaribo, 2013.

24. World Health Organization. Global Physical Activity Questionnaire (GPAQ) Analysis Guide. http://www.who.int/chp/steps/resources/ GPAQ_Analysis_Guide.pdf

25. Shin JY, Kim JY, Kang HT, et al. Effect of fruits and vegetables on metabolic syndrome: a systematic review and meta-analysis of randomized controlled trials. Int J Food Sci Nutr 2015;66:416-25.

26. Misra A, Sharma R, Gulati S, et al. Consensus dietary guidelines for healthy living and prevention of obesity, the metabolic syndrome, diabetes, and related disorders in Asian Indians. Diabetes Technol Ther 2011;13:683-94.

27. Haskell WL, Lee Intramuscular, Pate RR, et al. Physical activity and public health: updated recommendation for adults from the American College of Sports Medicine and the American Heart Association. Circulation 2007;116:1081-93.
28. Chackrewarthy S, Gunasekera D, Pathmeswaren A, et al. A Comparison between Revised NCEP ATP III and IDF Definitions in Diagnosing Metabolic Syndrome in an Urban Sri Lankan Population: the Ragama Health Study. ISRN Endocrinol 2013;2013:320176.

29. Fernandez-Berges D, Cabrera de Leon A, Sanz H, et al. Metabolic syndrome in Spain: prevalence and coronary risk associated with harmonized definition and WHO proposal. DARIOS study. Rev Esp Cardiol (Engl Ed) 2012;65:241-8.

30. Gavrila D, Salmeron D, Egea-Caparros JM, et al. Prevalence of metabolic syndrome in Murcia Region, a southern European Mediterranean area with low cardiovascular risk and high obesity. BMC Public Health 2011;11:562.

31. Khosravi-Boroujeni H, Ahmed F, Sadeghi M, et al. Does the impact of metabolic syndrome on cardiovascular events vary by using different definitions? BMC public health 2015;15:1313.

32. Cohen JC, Kiss RS, Pertsemlidis A, et al. Multiple rare alleles contribute to low plasma levels of HDL cholesterol. Science 2004;305:869-72.

33. Kolovou GD, Anagnostopoulou KK, Salpea KD, et al. The prevalence of metabolic syndrome in various populations. Am J Med Sci 2007;333:362-71

34. Kim C, Halter JB. Endogenous sex hormones, metabolic syndrome, and diabetes in men and women. Curr Cardiol Rep 2014;16:467.

35. El Mabchour A, Delisle H, Vilgrain C, et al. Specific cut-off points for waist circumference and waist-to-height ratio as predictors of cardiometabolic risk in Black subjects: a cross-sectional study in Benin and Haiti. Diabetes Metab Syndr Obes 2015;8:513-23.

36. Okosun IS RC, Forrester TE, Fraser $\mathrm{H}$. Predictive value of abdominal obesity cut-off points for hypertension in Blacks from West African and Caribbean island nations. Int $J$ Obes Relat Metab Disord 2000;24:180-6.

37. Arguelles W, Llabre MM, Sacco RL, et al. Characterization of metabolic syndrome among diverse Hispanics/Latinos living in the United States: latent class analysis from the Hispanic Community Health Study/Study of Latinos (HCHS/SOL). Int J Cardiol 2015;184:373-9.

38. Falkner B, Cossrow ND. Prevalence of metabolic syndrome and obesity-associated hypertension in the racial ethnic minorities of the United States. Curr Hypertens Rep 2014;16:449.

39. Bhadoria AS. Metabolic syndrome and associated risk factors. $J$ Family Community Med 2015;22:57.

40. Shah A, Hernandez A, Mathur D, et al. Adipokines and body fat composition in South Asians: results of the Metabolic Syndrome and Atherosclerosis in South Asians Living in America (MASALA) study. Int J Obes (Lond) 2012;36:810-16.

41. Gujral UP, Narayan KM, Kahn SE, et al. The relative associations of beta-cell function and insulin sensitivity with glycemic status and incident glycemic progression in migrant Asian Indians in the United States: the MASALA study. J Diabetes Complicat 2014;28:45-50.

42. Kaur J. A comprehensive review on metabolic syndrome. Cardiol Res Pract 2014;2014:943162. 